Association for Information Systems AIS Electronic Library (AISeL)

Wirtschaftsinformatik Proceedings 2003

Wirtschaftsinformatik

September 2003

\title{
Business Models for the Public WLAN Market
}

Amar Shubar

University of Bremen

Ulrike Lechner

University of Bremen, lechner@tzi.de

Follow this and additional works at: http://aisel.aisnet.org/wi2003

\section{Recommended Citation}

Shubar, Amar and Lechner, Ulrike, "Business Models for the Public WLAN Market" (2003). Wirtschaftsinformatik Proceedings 2003. 10 .

http://aisel.aisnet.org/wi2003/10

This material is brought to you by the Wirtschaftsinformatik at AIS Electronic Library (AISeL). It has been accepted for inclusion in Wirtschaftsinformatik Proceedings 2003 by an authorized administrator of AIS Electronic Library (AISeL). For more information, please contact elibrary@aisnet.org. 
In: Uhr, Wolfgang, Esswein, Werner \& Schoop, Eric (Hg.) 2003. Wirtschaftsinformatik 2003: Medien - Märkte - Mobilität, 2 Bde. Heidelberg: Physica-Verlag

ISBN: 3-7908-0111-9 (Band 1)

ISBN: 3-7908-0116-X (Band 2)

(C) Physica-Verlag Heidelberg 2003 


\title{
Business Models for the Public WLAN Market
}

\author{
Amar Shubar, Ulrike Lechner
}

University of Bremen

WLAN is a radical technology, enabling new ways to provide mobile access. A number of established and new companies have entered the mobile market with new business models. It is yet not clear how these new business models affect the mobile industry and which of them will really succeed. In our article, we introduce a new framework to support the development of new business models driven by new and radical technologies and apply it to the WLAN technology.

Keywords: Public WLAN, Business Models, Mobile Business

\section{Introduction}

Short-range wireless technologies such as IEEE 802.11, HyperLAN, HomeRF, Bluetooth, etc. are designed to cover areas with a diameter from 10 to a few hundred meters ${ }^{1}$. WLAN technologies cover - compared to mobile Internet access via GSM or UMTS - a small area at significantly lower initial costs. Access points are presently available for as little as 200 EUR. Due to their decentralized architecture, open Internet standards, and low cost base, these technologies have the potential to enable mobile telecommunication services using innovative business systems, independent of the respective standard (IEEE 802.11, HyperLAN, etc.). Thus, they can change the established value chain on a mid- or long-term basis.

Together with the low level of complexity and the low-cost base, this technology has enabled new industry outsiders with - in some cases - new business systems to enter the mobile market. These new business systems range from the commercial provision of mobile Internet access for traveling business customers to coverage of entire city sectors by non-commercial associations.

In addition to the assumed technological competition for future data traffic, these new business systems also compete with the existing business systems of today's

In the following article, WLAN technologies will be used to refer to all short range wireless technologies, such as IEEE 802.11, Bluetooth, HyperLAN, etc 
mobile phone providers. Moreover, they provide new commercial relationships within the value chain. Internet access has become ubiquitous and online services can be "added" to any conventional physical point of sale. This opens up a wide field for new services, innovative business systems and novel ways for traditional and electronic distribution and procurement channels to converge.

Our research focuses on the impact of the technology on the business systems and, in particular, on the business system of the network operator whose role is to provide and control the new channels. We have developed a new framework to support the development of new business systems driven by new and radical technologies ${ }^{2}$. In this article, we introduce this new framework in section 2 and apply the framework to analyze the PWLAN ${ }^{3}$ market driven by the WLAN technology in section 3 .

\section{Frame concept}

The frame concept supports the development of new business systems driven by new and radical technologies and helps in understanding the new industry.

Stähler [Stäh01b] defines a business model as a view on a business [business system] and a description of how the business [business system] functions. The business model is a tool for analysis on which strategies can be based. The business system is the object and a real instance, which is represented by the business model. Referring to Stähler [Stäh01b] the main components of the business model are the value proposition, the value architecture and the revenue model. There are also other definition of the business model like Alt and Zimmermann [AlZi01], Hamel [Hame03] and Timmers [Timm98]. Our Framework is based mainly on the business model definition of Stähler, as it provides a clear structure for a business model (see also Figure 2). We will also use the term business model for a group of business systems, which share the same abstract business model.

The Framework consists of four modules, which describe the steps of the analysis and design process. Note that it is typically necessary to iterate the process with its four modules. Each iteration may provide a better understanding of the new industry and its value chain. Compared to other idea generating frameworks like $\mathrm{TRIZ} / A R I Z^{4}$, the IDEA Framework does not seek for the "ideal machine" or try to solve a concert problem. Focus of our framework is to discover the new innovation space enabled by the new technology and to identify not one but several interacting business models. The four modules are described in the following.

see definition Henderson and Clark for radical innovation [HeCl90, P. 12]

the public WLAN market (PWLAN) is defined in the third chapter

see [Zobe $01,72 \mathrm{f}$.] 


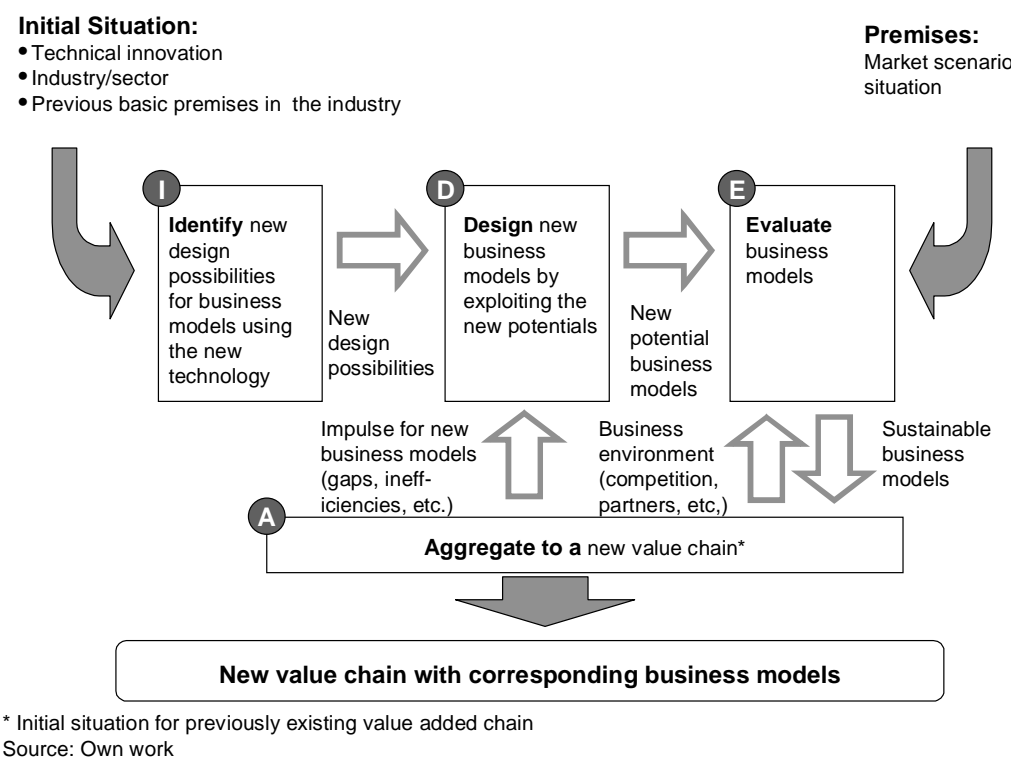

Figure 1: IDEA frame concept

\subsection{Module I - Identify new design possibilities}

The output of Module I is to identify the new design possibilities for business models resulting from the new technology. The three key guiding questions in module I are:

- Which industries are affected?

- Which business models of those industries are most affected? In how far do the basic assumptions of each business model need to be rethought?

- What are the new design possibilities of the new assumptions?

While the first question focuses only on the relevant industries, the second question is formulated on the hypothesis of Slywotzky [Slyw99, P. 32] that an industry and its business models are built on specific assumptions about the mechanism of the industry. Business models of mature industries are optimized based on theses assumptions. As long as these assumptions are correct, the business models are still optimized and there is no reason to change them. A new technology that changes these assumptions also effects the optimization of these business models. The business models have then to be optimized based on the changed new assumptions. These new assumptions may affect not only the performance of the 
business model but also the possibilities of how the business model could be designed. We call theses new possibilities to design business model new design possibilities. They are options for a business model innovation and could be used to improve and to optimize the business model (cf. [Stäh01]).

High potentia

Medium potential

Low potential

\begin{tabular}{|c|c|c|c|c|c|c|}
\hline \multicolumn{2}{|c|}{$\begin{array}{l}\text { Assumptions } \\
\text { Business model } \\
\text { Components }\end{array}$} & $\begin{array}{c}\text { New } \\
\text { Assumption } \\
1\end{array}$ & $\begin{array}{c}\text { New } \\
\text { Assumption } \\
2\end{array}$ & $\begin{array}{c}\text { New } \\
\text { Assumption } \\
3\end{array}$ & $\cdots$ & $\begin{array}{c}\text { New } \\
\text { Assumption } \\
\mathrm{n}\end{array}$ \\
\hline \multicolumn{2}{|r|}{ Value proposition } & & & & & \\
\hline \multirow{4}{*}{ 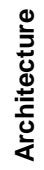 } & Product/market & & & & & \\
\hline & Internal architecture & & & & & \\
\hline & External architecture & & & & & \\
\hline & Stability of architecture & & & & & \\
\hline & Revenue model & & & & & \\
\hline
\end{tabular}

Source: Stähler 2001, P.47 and own work

Figure 2: Identifying the potential impact of the new assumptions

The matrix presented in Figure 2 supports the task of evaluating the effect of the new assumptions (caused by the new technology) on the business model. The components of a business model $^{5}$ are: value proposition, product/market, internal and external architecture, stability of the architecture, and the revenue model.

After the new assumptions have been identified, they are evaluated for each business model component as to whether there is a high, medium or low potential in that they affect this component. A new assumption that has a high potential on a business model component is a hint for design possibilities with high impact on this component. After completing the matrix each business model part has to be examined for new design possibilities considering those new assumptions, which have a potential effect on it. The new business models will then evolve from the initial old business models by utilizing these identified new design possibilities.

5 Using the business model partition of Stähler [Stäh01, P. 47] 


\subsection{Module D - Design new business models}

The output of Module D is a set of new business models using the new design possibilities identified in Module I. The construction of the module is oriented on the morphological method of Zwicky [Zwic66, P. 116] ${ }^{6}$. The core element is to identify the dimensions, which determine the solution, and the corresponding concrete options of each dimension. Possible solutions to the problem are the combinations of the options along the dimensions. They are then evaluated. The three key guiding questions in module $\mathrm{D}$ are:

- Which design possibilities are options of one dimension? What are all the options of one dimension?

- Which dimensions have the highest impact on the business model?

- What are the most useful combinations of options?

The first question takes account of the fact that the resulting design possibilities from Module I are for examples new customer segments X and Y. These design possibilities have to be aggregated to one design dimension - target customer segment. Design options of one dimension has to be formulated as such, that they exclude each other ${ }^{7}$. All useful options of one dimension have to be identified.

The aim of the second question is to reduce the number of combinations and, thus, the complexity of the problem. The dimensions are ranked according to their impact on the business model. Only those dimensions with the highest impact on the business model are further on considered, as they determine most of the innovation potential and the performance of the business model.

The third question is about identifying those options that characterize the business models with the highest potential. Potential business models are constructed on the basis of combinations of options from dimensions with the highest impact on business models. To formulate the complete business model for each combination, the residual options with lower impact are added. Unpromising combinations should be eliminated in advance to reduce the number of combinations and, thus, the complexity. The result of the module is then a set of potential business models.

\subsection{Module E - Evaluate business models}

In Module E, the potential business models (the result of module D) are evaluated in the market. The goal is to identify those business models, which have the potential to succeed in a market.

\footnotetext{
the concept is also used for product development [Nies+97, P. 265]

e.g. option 1 is customer segment $\mathrm{X}$ and not $\mathrm{Y}$, option 2 is $\mathrm{Y}$ and $\mathrm{X}$, option 3 is $\mathrm{Y}$ and $\mathrm{X}$
} 
The three key guiding questions in module $\mathrm{E}$ are:

- What are the relevant market assumptions?

- What is the performance ranking of each business model assuming the different market scenarios?

- What is the minimum business model ranking that is likely to survive?

In module $\mathrm{D}$, we have formulated the business models and the products/services they offer. In module $\mathrm{E}$, we formulate the relevant dimensions of the demand for these products/services and evaluate the business models.

Note, that this module is not about giving a market forecast. It is like a break-even analysis - what market assumptions do we have to make to believe that the business models under consideration will endure. We suggest considering three market assumption scenarios: worst, base, and best case. The business models are ranked against each other according to their performance in the different scenarios. The ranking mechanism can range from quantitative business case calculations (e.g., discounted cash flow method) to purely qualitative scoring-model based on benchmark questions. The questions should cover the business aspect revenue, cost and risk, which determine the performance of the business model.

Note that the level of detail of the scenarios should be according to the level of detail of the business models. So, as the business model descriptions become more sophisticated with each iteration, so will the scenarios. The ranking mechanism should (like the market scenarios) adopt the same level of detail as the business model. So, as the description of the business models becomes more sophisticated in each iteration, the ranking mechanism should consider these new aspects. One framework that supports a qualitative ranking has been introduced by Afuah and Tucci [AfTu01, P. 80]. The framework supports the ranking of the business models by using benchmark questions for each part of the business model.

After having ranked the models, we draw a line between those business models that will probably survive and those that will not. Those that are probably not profitable, and will not survive, are not considered in the following module.

\subsection{Module A - Aggregate to the new value chain}

In Module A, the business models are integrated in a value chain. The aim is to understand the environment of the single business models that have been identified up to now as well as the dynamics and the interaction between the business models and thus in the industry. Also, new assumptions and new design possibilities that initiate the next iteration are identified here.

The three key guiding questions are:

- How can the business models be ordered into a value chain? 
- How do the business models interact and what are the dynamics of the industry?

- Do new design possibilities arise?

Porter [Port96, P. 59] introduced the concept of the value chain. It is a good framework to compare the activities of the business models with each other and to analyze the interaction of business models.

The first step is, therefore, to identify the value-adding activities on the industry level. These activities have to be carried out to produce a service/product and to deliver it to the end user. The business models can then be structured according to the order of their activities. As a first orientation, the value chain of the initial business model or the value chain from the previous iteration can be used.

The second question is about the interaction of the business model and the resulting industry dynamic. There are three kinds of interaction: (1) Service relationships, (2) Competition, and (3) Alliances / Coalitions. All three of them need to be analyzed. This is described below.

Service relationships are the exchange of services, products or money between business models. These service relationships have to be coordinated. Coordination mechanisms as a part of the external architecture could be also areas of new design possibilities.

Competition can be defined as the struggle between two or more units regarding a scarce resource [Acad02] - demand can be also seen as a resource. Porter's five forces [Port88] is a good concept to analyze the intensity of the competition and predict the margin and, thus, the power allocated in an industry field. The five forces are: suppliers, buyers, industry competitors, substitutes, and the threat of new entrants. The analysis of the five forces can be based on the service relationships we have identified previously. Suppliers and buyers can be identified through the service relationships. Competing business models have service relationships with similar suppliers and buyers as they compete for the same resources. The common activities and the common value added of these competing business models helped us to understand better, what other product/services might substitute these values, and what market barriers exist to protect the market. It also helps us to identify not previously recognized parts of the value chain.

Alliances or coalitions are the third kind of relationship between business models. Fuller and Porter [FuPo86, P. 325] describe four motivations for a coalition: gaining economies of scale, gaining access to knowledge, risk sharing, and shaping the competition. Coalitions can be made between enterprises that have common activities (Y-coalitions), or enterprises doing different activities (X-coalitions) in the value chain. When the value chain is analyzed, we have to ask how the business model can improve its position through a coalition and with whom it could cooperate. 
In this module we lift the discussion from isolated business models and isolated markets to whole value chains and industries. A business model is only then successful when the cooperating business models in the respective value chain have also the potential to succeed within the market scenarios and according to the evaluation criteria that have been used before.

The analysis of the interaction between the business models helps us to identify new industry assumptions and mechanisms. The third question is about new design possibilities that could make a further iteration of the process necessary.

\section{Business models in the PWLAN sector}

The public WLAN (PWLAN) market is the public offering of communication services (data and voice) by using short range wireless technologies. First services started in the USA in 1999 followed from Europe in 2000. The number of PWLAN hotspots ${ }^{8}$ in Western Europe is assumed to be around 1000 [Thor02] in end of 2002. Forecast for yearly PWLAN revenue in 2006 range between 0.8 billion EUR [Lone02, P. 2] and 3.1 billion EUR [Pow01] in Western Europe. The biggest Players in Western Europe -according number of hotspots -are the Scandinavian mobile network operators Telia, Sonera and Telenor and the Austrian start up Metronet [Thor02].

Today PWALN services are mainly broadband Internet access. Voice services (Voice over IP) are technical possible, but mass-market solutions are still in development ${ }^{9}$. Today most location-based services in the PWLAN area are local promotions of the location owners.

Most PWLAN operator are focusing on business travelers or so called nomadic workers as their adoption rate and bandwidth consumption are high while their price sensitivity is low. Therefore favored hotspot locations are places like business hotels, airports, fairs and conference centers. Examples are the Munich Airport and the fair of Hannover which running a Public WLAN on their own.

As the main value proposition of PWLAN operator is to provide cheap broadband wireless Internet access, it affects the ISP and the mobile telecommunication market. Most Mobile Network operators (MNO) have announced to start or already started PWLAN offering ${ }^{10}$. ISP player have a good position to enter the market, as they already cover a substantial part of the PWLAN value chain. Regardless of their good positions no mayor ISP Player has entered the market yet.

\footnotetext{
8 places where PWLAN is offered

9 Avaya, Motorola and Proximm are working on a WLAN mobile phone with integrated Voice over IP [Heis03]

10 examples are Telia, T-Mobile, vodaphone and $\mathrm{mmO} 2$
} 
Besides some technical issues the uncertainty about the right business model are the key challenges the PWLAN market has to overcome [Lone02, P. 9].

The IDEA framework presented in the previous section is now applied to analyze the business models related to the PWLAN market and the WLAN technology. Note that we focus in our analysis on the business model mobile network operator and present only one iteration of the IDEA framework.

\subsection{Identifying new WLAN design possibilities}

The basic assumption of the two convergent mobile and internet service industry and in specific the assumption of the business models of the mobile operator and the ISP are most effected by the WLAN technology: As both business models could be used as starting points to evolve new business models for the PWLAN market, we will focus in this article only on the business model of the mobile network operator (MNO) as a starting point. Figure 3 shows how the WLAN technology effects the basic assumption of the mobile operator and outlines the new assumptions.

\begin{tabular}{|c|c|c|}
\hline $\begin{array}{l}\text { Business Model } \\
\text { Components }\end{array}$ & $\begin{array}{l}\text { Basic Assumptions of } \\
\text { Mobile Network Operator }\end{array}$ & $\begin{array}{l}\text { New Assumptions } \\
\text { when using WLAN }\end{array}$ \\
\hline \multirow[t]{2}{*}{ Value Proposition } & $\begin{array}{l}\text { - National coverage is main quality } \\
\text { criteria }\end{array}$ & $\begin{array}{l}\text { Limited coverage in exchange for } \\
\text { high and cheap bandwidth is } \\
\text { acceptable. Type of location effecting } \\
\text { user's behavior }\end{array}$ \\
\hline & $\begin{array}{l}\text { - National offer. Simple site rental } \\
\text { agreements }\end{array}$ & $\begin{array}{l}\text { - Local offer effecting attractiveness of } \\
\text { location an thus location owners } \\
\text { business, tight interaction necessary }\end{array}$ \\
\hline \multirow[t]{3}{*}{ Architecture of Production } & $\begin{array}{l}\text { - High specialized know-how and } \\
\text { Investments necessary => high } \\
\text { market entry barrier and } \\
\text { therefore control of the value } \\
\text { chain by network operators }\end{array}$ & $\begin{array}{l}\text { No special know-how for access } \\
\text { point installation necessary. Small } \\
\text { initial investment. Using standard- } \\
\text { technology }\end{array}$ \\
\hline & $\begin{array}{l}\text { - Integrated system with limited } \\
\text { programmable client. Account } \\
\text { installation with SIM-card }\end{array}$ & $\begin{array}{l}\text { Flexible programmable client with } \\
\text { reduced security. Online account } \\
\text { installation e.g. by using username } \\
\text { and password }\end{array}$ \\
\hline & $\begin{array}{l}\text { - Allocation of a specific frequency } \\
\text { spectrum nationwide. Ownership } \\
\text { of Access Infrastructure }\end{array}$ & $\begin{array}{l}\text { - Free frequency spectrum -> } \\
\text { exclusive coverage per location } \\
\text { necessary. Access Infrastructure } \\
\text { can be owned by other party }\end{array}$ \\
\hline Revenue Model & $\begin{array}{l}\text { - Subvention of the special devices } \\
\text { necessary }\end{array}$ & - Many users already have devices \\
\hline
\end{tabular}

Source: Own Work

Figure 3: Effect on the basic assumptions of the MNO business model 
We assume as the basis for our analysis that the new assumptions "No special know how / small initial investment" and "free frequency spectrum", are the most significant changes between the old assumptions of the MNO business model (representative for the mobile telecommunications market) and the new assumptions in the WLAN sector as they abolish the common market entry barriers of the mobile telecommunication markets (cf. UMTS license fees and the costs for building up an mobile telecommunications infrastructure).

The effects of the new assumptions on the business model are depicted in Figure 4. The columns are the new assumptions detailed in Figure 3. The rows are the components of a business model. Note that a new assumption can affect several business models parts and enables in them several new design possibilities. Not every dot however is one design possibility. Several new assumptions can in combination enable one new design possibility in a business model part.

\begin{tabular}{|c|c|c|c|c|c|c|c|}
\hline & & & & & & $\begin{array}{l}\text { High } p \\
\bigcirc \text { Mediu } \\
\bigcirc \text { Low }\end{array}$ & $\begin{array}{l}\text { tential } \\
\text { potential } \\
\text { ential }\end{array}$ \\
\hline $\begin{array}{l}\text { Part } \\
\text { bus }\end{array}$ & $\underbrace{\begin{array}{l}\text { New } \\
\text { assumptions }\end{array}}_{\substack{\text { of } \\
\text { iness } \text { model }^{*}}}$ & $\begin{array}{l}\text { Limited } \\
\text { coverage }\end{array}$ & Local Offer & $\begin{array}{l}\text { Small } \\
\text { initial } \\
\text { Investments } \\
\text { and } \\
\text { know-how } \\
\end{array}$ & \begin{tabular}{|l|}
$\begin{array}{l}\text { Flexible } \\
\text { programm. } \\
\text { able Client }\end{array}$ \\
\end{tabular} & $\begin{array}{l}\text { Using free } \\
\text { frequency } \\
\text { spectrum }\end{array}$ & $\begin{array}{l}\text { Users } \\
\text { already } \\
\text { have } \\
\text { devices }\end{array}$ \\
\hline & Value proposition & 0 & 0 & & & & \\
\hline 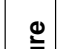 & Product/market & 0 & 0 & & & & \\
\hline 胥 & Internal architecture & 0 & 0 & 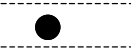 & 0 & 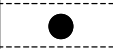 & 0 \\
\hline 苨 & External architecture & & 0 & 0 & 0 & 0 & 0 \\
\hline 玄 & Stability of architecture & & & & O & 0 & \\
\hline & Revenue model & & & & 0 & & 0 \\
\hline
\end{tabular}

Source: Stähler 2001, P.47 and own work

Figure 4: Identifying the impact of the new assumptions

Note that all business model parts are affected. The internal architecture is most affected as it is affected by all new assumptions. As mentioned above the assumptions "No special know how / small initial investment" and "free frequency spectrum" have the biggest impact on the business model. We expect that those new assumptions both have high impact on the internal architecture of a business model. Since no "special knowledge" is necessary - the players in the market do not need to dispose of human capital and there is no need for huge upfront invest- 
ments in license fees. According to the impact on the financial aspects of the business models, we decide to rate the impact of those two factors to be very high.

\subsection{Designing new WLAN business models}

The identification of new design possibilities is demonstrated with the business model part "internal architecture". Figure 4 shows that all new assumptions have a potential impact on the internal architecture of the business model. The new assumptions "No special know how / small initial investment" and "free frequency spectrum" combined with the other assumption enable that almost everybody could provide a PWLAN service. Owners of a PWLAN service could be location owner or even private persons, who may have a different cost structure as a company specialized on PWLAN services.

The new assumption enables new ownership models mainly in the access part of the value chain. For the other value chain parts, they have to relay on other service provider. This leads to a new composition of the internal value chain.

In table 1 the identified new design possibilities are listed in brackets for each business model part. The corresponding design dimensions are formulated before them. In order to rank their impact on the business model performance, we used the following criteria:

1. How strong does it determine other business model parts?

(High / Low)

2. How difficult is it to change (afterwards)?

(High / Low)

Design dimensions with two "Highs" are ranked high (H) with one middle (M) and with no one low (L) in table 1.

We assume that the design dimensions Ownership and Composition of the value chain have the highest impact on the business model performance, as they very strongly determine the other business model parts and are very difficult to change afterwards.

After we have identified the design dimensions with the highest impact, we will determine their design options. In order to do that for the dimension composition of the value chain we use the value chain of the mobile network operator. The value chain used in Figure 5 is an adopted version of the value chain presented by Tewes [Tewe97, P. 18]. In the value chain we mark the design options, i.e., the activities and combinations of activities of the value chain that seems to be useful. We also name those design options. We identify nine different useful design options. Note that with a black line we depict a scope in the value chain that is mandatory and with a gray line we define optional fields in the value chain. Functions not marked with a line are excluded from this specific design option. All design options exclude each other. 


\begin{tabular}{|c|c|c|c|}
\hline \multicolumn{2}{|c|}{$\begin{array}{l}\text { Business model } \\
\text { component }\end{array}$} & New design dimensions (new design possibilities) & Rank \\
\hline \multicolumn{2}{|c|}{ Value Proposition } & $\begin{array}{l}\text { Value Proposition for PWLAN users: } \\
\text { (Cheap internet broadband access in Hot Spots, } \\
\text { Wide area coverage through roaming with 2G/3G) } \\
\text { Value Proposition for location owner: } \\
\text { (Additional revenue stream for location owner, } \\
\text { Benefits in location owners main business, integration } \\
\text { in location owners main business) }\end{array}$ & M \\
\hline \multirow{4}{*}{ 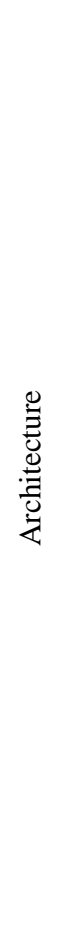 } & $\begin{array}{l}\text { Product/ } \\
\text { Market }\end{array}$ & $\begin{array}{l}\text { New Services (Local Internet Access, Voice over IP, } \\
\text { integrated location based services) } \\
\text { Rollout strategy (single location, multi location) } \\
\text { Location type mix (hotels, airports, etc.) }\end{array}$ & $\begin{array}{l}M \\
M\end{array}$ \\
\hline & $\begin{array}{l}\text { Internal Ar- } \\
\text { chitecture. }\end{array}$ & $\begin{array}{l}\text { Ownership (specialized company, location owner, pri- } \\
\text { vate person) } \\
\text { Composition of the internal value chain }\end{array}$ & $\begin{array}{l}\mathrm{H} \\
\mathrm{H}\end{array}$ \\
\hline & $\begin{array}{l}\text { External Ar- } \\
\text { chitecture. }\end{array}$ & $\begin{array}{l}\text { Distribution channel for access (physical at point of } \\
\text { sale POS, online at POS, roaming partners) } \\
\text { Collecting customer information (for profiling, for } \\
\text { selling) } \\
\text { Communication channel of the location owner (for lo- } \\
\text { cal content, business transaction - e.g. ordering) } \\
\text { Extended Roaming variants (bi lateral, multi lateral, } \\
\text { exclusive) } \\
\text { New Value chain partners (corresponding to the inter- } \\
\text { nal value chain) }\end{array}$ & $\begin{array}{l}\mathrm{L} \\
\mathrm{L} \\
\mathrm{M} \\
\mathrm{M} \\
\mathrm{M}\end{array}$ \\
\hline & $\begin{array}{l}\text { Level of } \\
\text { Stability }\end{array}$ & Increased flexibility in the value-chain architecture & $\mathrm{L}$ \\
\hline \multicolumn{2}{|c|}{ Revenue model } & $\begin{array}{l}\text { New Revenue sources (User information, increased } \\
\text { Cross-selling for location owner) } \\
\text { New Pricing options (No subvention of devices neces- } \\
\text { sary, free, flat fee) }\end{array}$ & M \\
\hline
\end{tabular}

Table 1: New design dimensions 


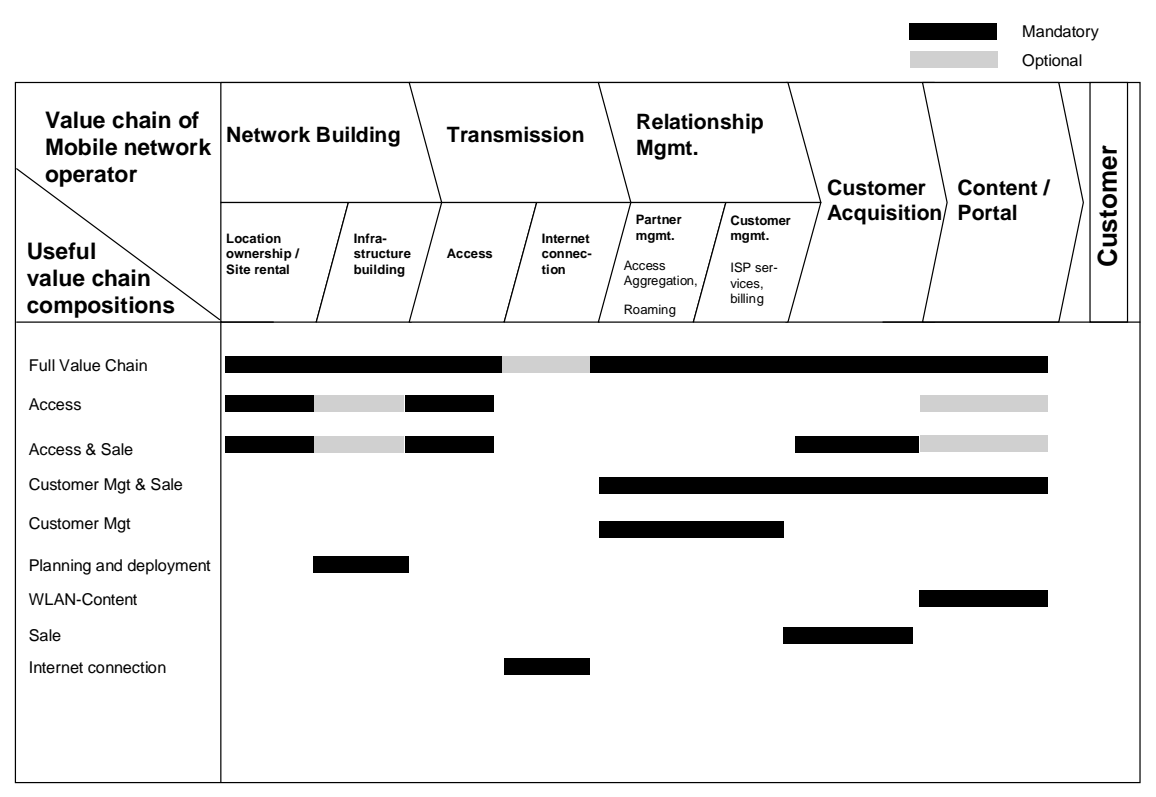

Source: Own Work, value chain based on Tewes [Tewes 1997, P. 18]

Figure 5: Useful value chain compositions and their names

There are three options for the design dimension ownership: A service could be offered form an:

- Specialized company, which exclusively runs this service. It is specialized on this service and thus can fulfill the know how and the investment needs for running this service. (Only option in the MNO business model)

- Professional location owner, who runs this service as a side production. He can reuse his location, personal and infrastructure of his main business and thus realize a cost advantage. (New Option)

- Private person, who runs this service as a side production. He uses his private location and infrastructure. All installations are done by himself and thus realizing a cost advantage as he not calculates with the regular labor cost. (New Option)

The two dimensions for which we have identified a high impact in Table 1, namely "Composition of the value chain" and "Ownership" and their design options are summarized below in Table 2. Note that the options of the dimension "Composition of the value chain" are summarized in Figure 5. The options of the design dimension "Ownership" have been discussed in the paragraph above. 
In order to combine the different options of the two design dimensions we use the morphological box in Table 2. A combination is a tuple compound by one option from each dimension.

\begin{tabular}{|l|l|l|l|l|l|l|l|l|l|}
\hline $\begin{array}{l}\text { Dimen- } \\
\text { sion }\end{array}$ & \multicolumn{7}{|c|}{ Options } \\
\hline $\begin{array}{l}\text { Compo- } \\
\text { sition of } \\
\text { the } \\
\text { value } \\
\text { chain }\end{array}$ & $\begin{array}{l}\text { Full } \\
\text { Value } \\
\text { Chain }\end{array}$ & $\begin{array}{l}\text { Ac- } \\
\text { cess }\end{array}$ & $\begin{array}{l}\text { Ac- } \\
\text { cess } \\
\&\end{array}$ & $\begin{array}{l}\text { Rela- } \\
\text { tion- } \\
\text { ship } \\
\text { Sale }\end{array}$ & $\begin{array}{l}\text { Mgt. } \\
\text { tion- } \\
\text { ship } \\
\text { Mgt. } \\
\text { Sale }\end{array}$ & $\begin{array}{l}\text { Plan- } \\
\text { and } \\
\text { de- } \\
\text { ploy- } \\
\text { ment }\end{array}$ & $\begin{array}{l}\text { Sa- } \\
\text { le }\end{array}$ & $\begin{array}{l}\text { Con- } \\
\text { tent }\end{array}$ & $\begin{array}{l}\text { Inter- } \\
\text { net } \\
\text { con- } \\
\text { nec- } \\
\text { tion }\end{array}$ \\
\hline $\begin{array}{l}\text { Owner- } \\
\text { ship }\end{array}$ & $\begin{array}{l}\text { Specialized Company } \\
\text { (exclusive production) }\end{array}$ & $\begin{array}{l}\text { Professional location Owner } \\
\text { (side production) }\end{array}$ & $\begin{array}{l}\text { Private Person } \\
\text { (side production) }\end{array}$ \\
\hline
\end{tabular}

Table 2: Morphological box

Sensible combinations of design options are selected and discussed further on:

- For professional location owner the value chain options "Relationship Mgt. \& Sale", "Relationship Mgt.", "Internet connection", "Planning and deployment" and "Content" only make sense in combination with an specialized company with exclusive production, as these value chains rely on scale to be successful. Therefore those combinations are not considered further on.

- For private person, only the value chain option "Access" as a side production seems to be manageable and therefore all other combinations of "Private Person" with the options of "Composition of the value chain" are not considered.

In order to evaluate potential business models we have to complete the business model description. In Figure 5 the identified business models are described with its number, a name, the design options from the dimensions "Ownership" and "Composition of the value chain" together with a description and some examples. 


\begin{tabular}{|c|c|c|c|c|c|}
\hline & Business Model & Owner Ship & Value Chain & Description of business model & Examples \\
\hline 1 & Fully Integrated Operator & $\begin{array}{l}\text { Specialized } \\
\text { Company }\end{array}$ & Full Value Chain & $\begin{array}{l}\text { Offers PWLAN Internet Access in multi locations. Owning most Access } \\
\text { Points as well having Roaming agreements with some access point } \\
\text { owners. }\end{array}$ & $\begin{array}{l}\text { BT, T-Mobile (Mobil } \\
\text { Star) }\end{array}$ \\
\hline 2 & WLAN-Service Provider & $\begin{array}{l}\text { Specialized } \\
\text { Company }\end{array}$ & $\begin{array}{l}\text { Relationship Mgt } \\
\& \text { Sale }\end{array}$ & $\begin{array}{l}\text { Offers PWLAN Internet Access in multi locations. Relying only on } \\
\text { roaming agreements with access provider }\end{array}$ & iPass, Boingo \\
\hline 3 & $\begin{array}{l}\text { Exclusive Professional } \\
\text { Access Provider }+\end{array}$ & $\begin{array}{l}\text { Specialized } \\
\text { Company }\end{array}$ & Access \& Sale & $\begin{array}{l}\text { Owns Access Points in multi locations. Has roaming agreements with } \\
\text { Service Providers. Sells contracts and prepaid cards for their own brand } \\
\text { (customer ownership) and for PWLAN Provider with which they have a } \\
\text { roaming agreement }\end{array}$ & - \\
\hline 4 & $\begin{array}{l}\text { Exclusive Professional } \\
\text { Access Provider }\end{array}$ & $\begin{array}{l}\text { Specialized } \\
\text { Company }\end{array}$ & Access & $\begin{array}{l}\text { Owns Access Points in multi locations. Has roaming agreements with } \\
\text { Service Provider, but does not have a sales force. }\end{array}$ & - \\
\hline 5 & Relationship Mgt. ASP & $\begin{array}{l}\text { Specialized } \\
\text { Company }\end{array}$ & Relationship Mgt & $\begin{array}{l}\text { Provides Access Provider + with customer authentification and billing } \\
\text { functionality -no customer ownership. Coordinates Roaming agreements } \\
\text { for access provider. }\end{array}$ & $\begin{array}{l}\text { monzoon, iPass, } \\
\text { Boingo }\end{array}$ \\
\hline 6 & WLAN-Content Provider & $\begin{array}{l}\text { Specialized } \\
\text { Company } \\
\end{array}$ & Content & $\begin{array}{l}\text { Offering Location based Services and Content for PWLAN in multi } \\
\text { locations.. }\end{array}$ & 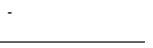 \\
\hline 7 & $\begin{array}{l}\text { Network Planning } \\
\text { Bureau }\end{array}$ & $\begin{array}{l}\text { Specialized } \\
\text { Company }\end{array}$ & $\begin{array}{l}\text { Planning \& } \\
\text { Deployment }\end{array}$ & $\begin{array}{l}\text { Specialized in planning and deployment of WLAN access points for } \\
\text { access provider }\end{array}$ & signa \\
\hline 8 & Reseller & $\begin{array}{l}\text { Specialized } \\
\text { Company }\end{array}$ & Sale & $\begin{array}{l}\text { Sells contract and prepaid cards for Fully Integrated Operator and WLAN } \\
\text { Service Provider in physical stores or online. }\end{array}$ & $\begin{array}{l}\begin{array}{l}\text { Retail stores, online } \\
\text { shops }\end{array} \\
\end{array}$ \\
\hline 9 & ISP & $\begin{array}{l}\text { Specialized } \\
\text { Company }\end{array}$ & $\begin{array}{l}\text { Internet } \\
\text { connection }\end{array}$ & $\begin{array}{l}\text { Connects the hotspots to the internet. Get fixed or traffic based fee from } \\
\text { PWLAN provider. }\end{array}$ & T-Online, Arcor net \\
\hline 10 & Small Operator (B/S) & $\begin{array}{l}\text { Professional } \\
\text { Location } \\
\text { Owner }\end{array}$ & Full Value Chain & Offers existing customer base an additional service only in this location. & $\begin{array}{l}\text { Hotels, Airline } \\
\text { Lounges, Restaurants }\end{array}$ \\
\hline 11 & $\begin{array}{l}\text { Professional Access } \\
\text { Provider + }\end{array}$ & $\begin{array}{l}\text { Professional } \\
\text { Location } \\
\text { Owner }\end{array}$ & Access \& Sale & $\begin{array}{l}\text { Own the Access Points in their location. Sells contracts and prepaid cards } \\
\text { for their own brand (customer onnership) and for PWLAN Provider with } \\
\text { which they have a roaming agreement. }\end{array}$ & $\begin{array}{l}\text { Hotels, Air Line } \\
\text { Lounges, , estaurants, } \\
\text { Trade Fairs, }\end{array}$ \\
\hline 12 & $\begin{array}{l}\text { Professional Access } \\
\text { Provider }\end{array}$ & $\begin{array}{l}\text { Professional } \\
\text { Location } \\
\text { Owner }\end{array}$ & Access & $\begin{array}{l}\text { Owns only the Access Points in their location. Has roaming agreements } \\
\text { with Service Provider, but does not have a sales force. }\end{array}$ & $\begin{array}{l}\text { Trade Fairs, } \\
\text { Univerities, Malls, } \\
\text { Hospitals }\end{array}$ \\
\hline 13 & POS Reseller & $\begin{array}{l}\text { Professional } \\
\text { Location } \\
\text { Owner }\end{array}$ & Sale & $\begin{array}{l}\text { Location Owner sells contract and prepaid cards for Fulll Integrated } \\
\text { Operator and WLAN Service Provider in the hotspot (point of service). }\end{array}$ & $\begin{array}{l}\text { Hotel, Restaurant, } \\
\text { Café Shop }\end{array}$ \\
\hline 14 & $\begin{array}{l}\text { Private Access } \\
\text { Provider }\end{array}$ & $\begin{array}{l}\text { Private } \\
\text { Person }\end{array}$ & $c c e s s$ & $\begin{array}{l}\text { Onss an private Access Point and offerss Internet access for free or has a } \\
\text { roaming agreement with a service provider. }\end{array}$ & $\begin{array}{l}\text { WAN Communities, } \\
\text { Bay Org }\end{array}$ \\
\hline
\end{tabular}

Figure 6: Identified business models

\subsection{Evaluation of the business model}

In module D, 14 business models have been identified (as depicted in Figure 6). Those business models are evaluated in this module. The relevant market assumptions for our business models are the penetration of WLAN-Hot spots users in the segments of business and consumer customer. We will focus on a static penetration rates. The three fictive assumed market scenarios are:

- Worst Case: Only business travelers will take advantage of WLAN hot-spots Low penetration (10-20\% of mobile business customers) in the business segment. No penetration in the consumer segment.

- Base Case: WLAN becomes a common access for business customers to Internet and their company's intranet. Only technology-affined consumers will use WLAN Hotspots. Medium penetration in the business segment (30-60\% of mobile business users) and low penetration in the customer segment (10-20\% of mobile business users).

- Best Case: WLAN becomes a common access for the business and consumer segment. High penetration in the business segment $(60-90 \%$ of mobile business users) and medium penetration in the customer segment (30-60\% of mobile business users).To adapt the level of detail of the business models, we 
suggest benchmarking questions concerning the business aspects revenue, cost and risk to rank the business models. The benchmark questions are summarized in table 3.

We suggest to evaluate each question for each of the market scenario with a mark between -2 (very poor) and +2 (very high) or $\mathrm{K}$. $\mathrm{K}$ is a killer mark and means that the business model will probably not survive, regardless of the evaluation of the other questions. Although we use a very simple ranking mechanism, it helps us to understand better the strengths and weaknesses of the models.

\begin{tabular}{|l|l|}
\hline \multirow{2}{*}{ Business Aspects } & Benchmark question \\
\hline Revenue & $\begin{array}{l}\text { 1. How distinctive is the value for customers compared } \\
\text { to other business models with the same value chain ac- } \\
\text { tivities? }\end{array}$ \\
\cline { 2 - 3 } Cost & $\begin{array}{l}\text { 2. How big is the target segment? } \\
\text { business models with the same value chain activities? }\end{array}$ \\
\cline { 2 - 3 } & $\begin{array}{l}\text { 4. How big is the assumed revenue compared to its in- } \\
\text { vestment needs? }\end{array}$ \\
\hline Risk & $\begin{array}{l}\text { 5. How independent is the business model of other new } \\
\text { business models? How stable are the new business mod- } \\
\text { els it relies on? }\end{array}$ \\
\hline
\end{tabular}

Table 3: Benchmarking question

Figure 7 shows the evaluation and the ranking of the business models for the different market scenarios. For each of the three market scenarios (Worst, Base, Best as defined above), we evaluate each business model according to the five benchmark questions 1-5 given in table 3. Their numbers refer to the questions.

In the worst-case scenario PWLAN users have to accept a fragmented and pure local offer. Also as PWLAN is not wide spread business models with a physical presence at the point of service (Business Models 10,11,12,13) and business models less independent from other business models or supporting these business models (Business Models 1,2,5,7,9) have the potential to succeed.

In the base case PWLAN users expect a national offer in multi locations. Therefore business models providing PWLAN in multi locations (Business Models 1,2) and business models supporting them (Business Models 12,13,14) have a good chance to survive. As the PWLAN has now a considerable size the WLANContent Provider business model will potentially endure. Relationship Mgt. ASPs profit from the increased number of professional access provider. They concen- 
trate on handling roaming agreements of small professional access provider and thus reduce cost of complexity and provide them with an aggregated negotiation power.

In the best case mostly the same business model as in the base case have the potential to survive. Only $\operatorname{POS}^{11}$ Reseller will not have a chance, as all customer acquisitions will probably be done online.

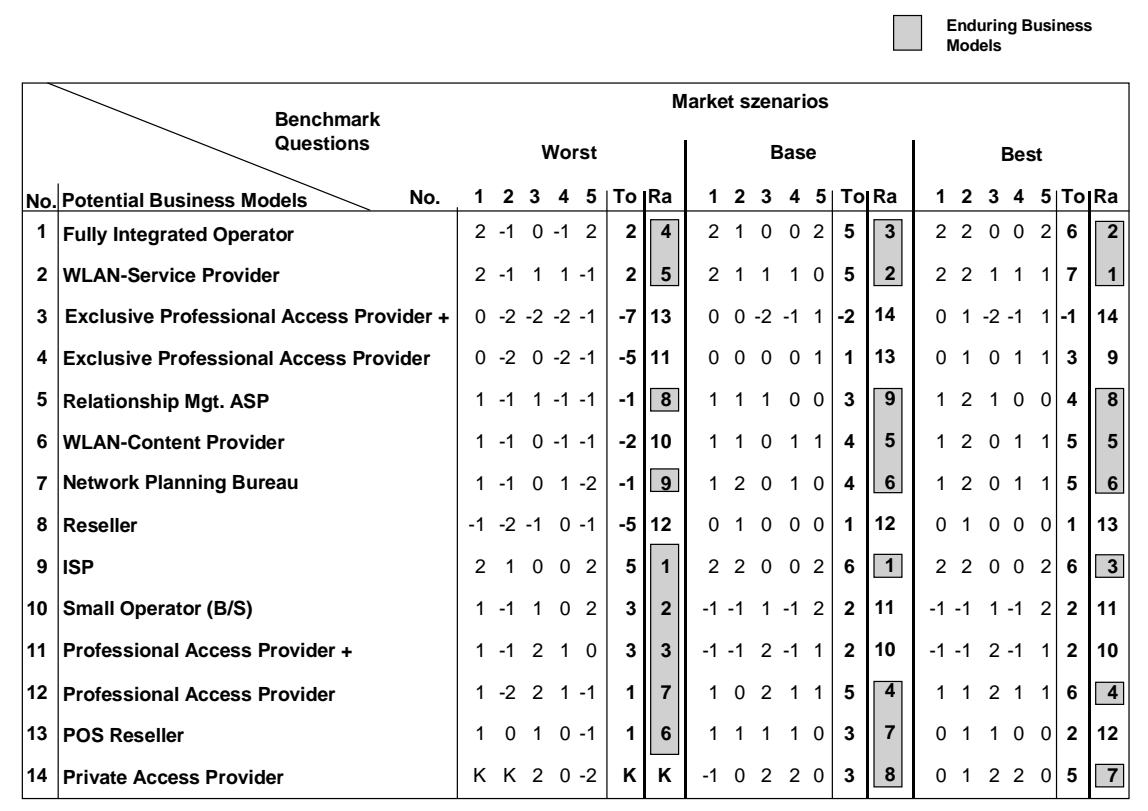

Source: Own work

Figure 7: Evaluation of the business models

The ISP business model is not much dependent on the PWLAN market as it generates its most revenue from the conventional Internet access. The only effect is an increase regarding it target segment in the base- and best-case scenario.

The business model exclusive professional access provider and exclusive professional access provider+ are in all market scenarios probably not successful as they have a cost disadvantage compared to the location owner models and are dependent from the location owner. Also reseller has an immanent value disadvantage compared to the POS Reseller.

11 POS - point of service 


\subsection{Aggregation to a new value chain}

In this section we will aggregate those business models to a new value chain, which at least survived in one scenario. We will analyze the dynamic in the value chain and thus of the new industry by outlining the service relationships, competition and alliance opportunities between the business models. By integrating the new business models into the value chain, we get the following picture, Figure 8 .

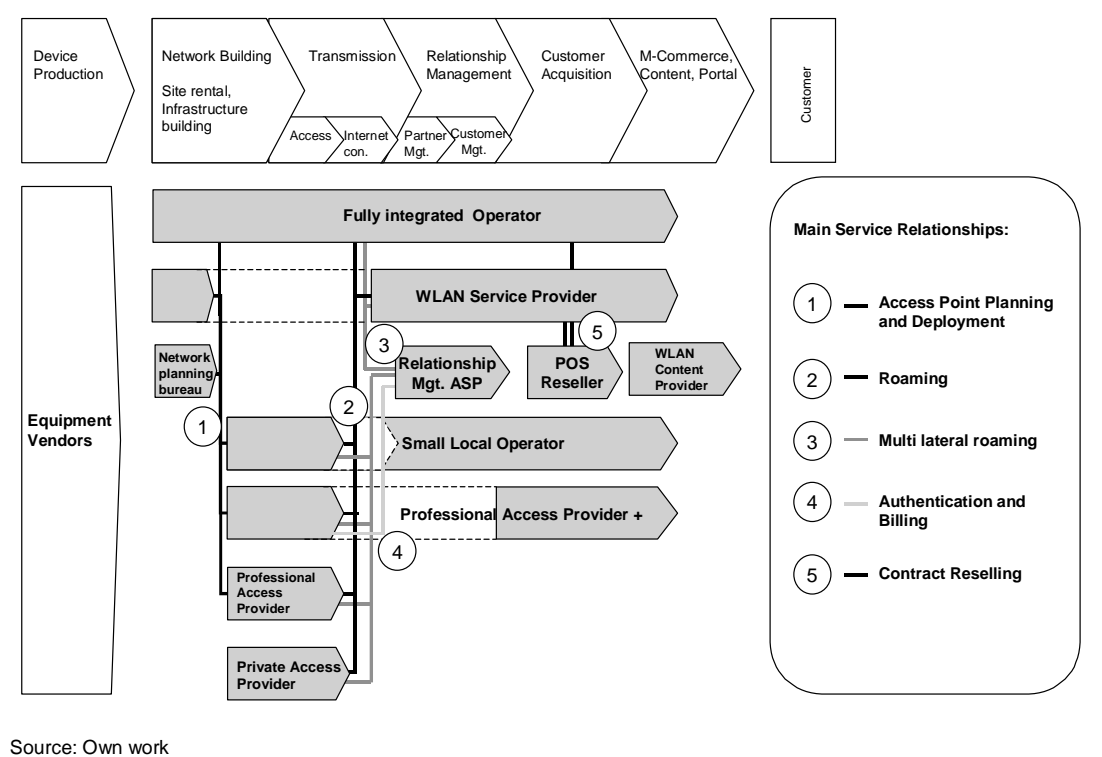

Figure 8: Value chain

\subsubsection{Service Relationships}

Four main service relationships can be identified between the business models:

- Access Point Planning and Deployment: Network planning and deployment of a network with several access points is complex and needs some experience. WLAN service providers and fully integrated operators offer their roaming partners (Professional Access Providers) help in the deployment of their network, as service providers and fully integrated operators have the organization and the experience to do so and gain from the increased network quality of their partners. Also a network-planning bureau offers these services as a neutral partner. 
- Roaming: Roaming is the main service relationship between the identified business models, as mostly all business models need roaming to aggregate enough customers for their service. Three kinds of roaming agreements could be differentiated between. The first one is the exclusive roaming of an access provider to an access aggregator ${ }^{12}$, the second one is the non-exclusive roaming of an access provider to an access aggregator, and the third one is roaming agreements between access aggregators.

- Multi lateral roaming: The pure bi-lateral roaming contracts with a high number of small access providers (e.g., for a nationwide roaming) has high transaction cost due to its complexity. Multi lateral roaming agreements and a roaming platform provided by a Relationship Mgt. ASP could reduce these costs. Additional he could provide small access providers with an aggregation mechanism to increase their negotiation power. Setting up technical and security standard helps to reduce transaction cost further.

- Authentication and Billing: Authentication and Billing especially in combination with roaming are rather complex. A specialized relationship Mgt. ASP can provide the necessary infrastructure.

\section{- Contract Reselling}

Fully integrated operators and WLAN service providers rely on nation-wide distribution of their service. For an efficient physical distribution channel, they have to partner with contract resellers. POS Resellers could be location owner, who already have a selling point from their main business (hotels, cafes, etc.).

\subsubsection{Competition}

Looking on the main activities of the value chain, we can identify three potential fields of competition: access providing and the two sub activities of relationship mgmt.: partner and customer mgmt.

With regard to access providing the competition is very limited as they mostly do not offer substituting products (covering the same area). The access providers also benefit ${ }^{13}$ from one another, as there is a network effect through any additional coverage, which increases the overall value to the end users. But access provider business models are competing against the option of renting the locations. The site rental price will be therefore set according their expectations of their own business case. Fully integrated operators compete against each other and against the location owner's business model for this scarce resource.

12 Access aggregators are business models who want to provide their customers with an increased coverage through roaming.

13 See also Porter [Port96, P. 267]. He describes the strategic benefit of competition which accrues when the competition covers less attractive segments (areas). Otherwise the original company would have to cover those segments on their own. 
With regard to partner mgmt. as part of the relationship mgmt. the competition is about providing the biggest coverage, to cover the area with the most traffic and to use it or to sell it to a third party (by roaming). The substituting product is their network coverage, as this is maybe overlapping. As far as customer management is concerned, it is about selling this network coverage to PWLAN users (own or users of partners) and bundling as many customer relationships as possible.

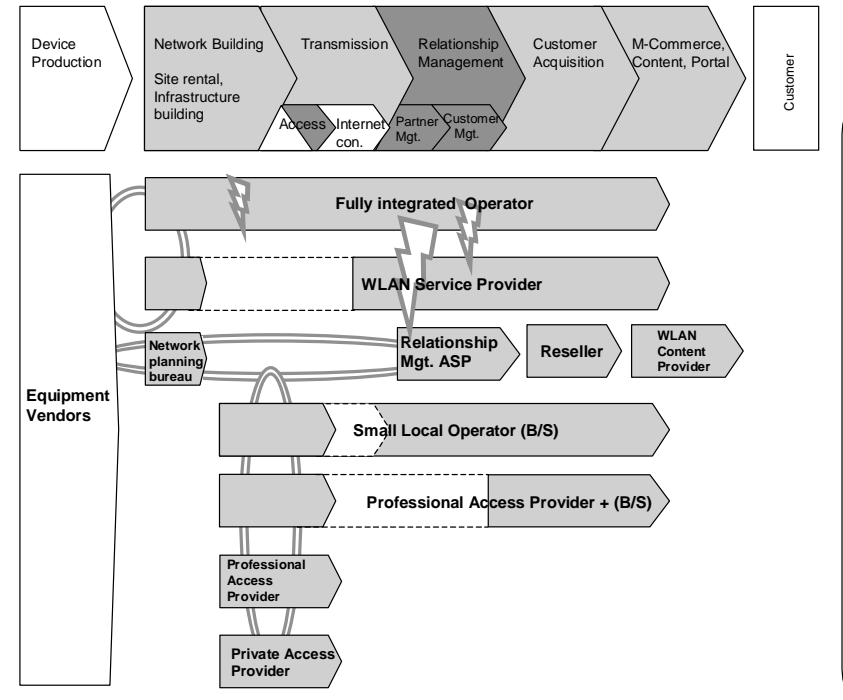

Source: Own work

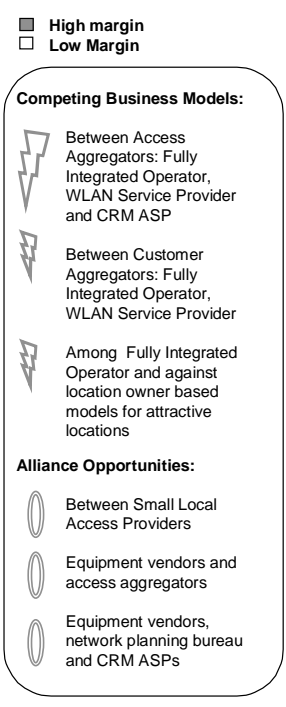

Figure 9: Analysis of the value chain

Most power in the value chain will be located in the activities of relationship management and, in some cases, in access providing. Both activities have market barriers enabling higher margins. Access providers owning the location have a resource advantage, which is not imitable. In high traffic areas, like airports, access providers can claim a supreme price. Relationship management (partner and customer management) is a scale business and, thus, companies can build market barriers through economies of scale.

\subsubsection{Alliances}

There are three potential alliance situations:

\section{- Between small local access providers}

Competition between access providers is very limited, as they do not have substitutable products. On the other hand, the value each access provider offers to 
the roaming partner is marginal (except in areas where there is high traffic airports, railway stations, trade fairs, etc). Thus, they have very limited bargaining power and cannot set a price. By building an alliance with other access providers, they can aggregate their bargaining power. This task could also be realized by a relationship mgt. ASP.

\section{- Equipment vendors / access aggregators}

Access aggregators could offer potential access providers/location owners an easy-to-install plug and play solution for a reduced price. Equipment vendors would benefit from increased sales. An example is Toshiba's cooperation with iPass [Grif02].

- Equipment vendors / network planning bureaus / Relationship Mgt. ASPs An example of this kind of cooperation is the alliance between Cisco, IBM, and monzoon [Monz2002]. While monzoon acts as a Relationship Mgnt. ASP, it can also offer its access provider network planning and deployment through its cooperation with Cisco and IBM.

\subsubsection{Impulses for the next iteration and new design possibilities}

The following are new impulses for the design and the evaluation of the business models:

- The profitability of the fully integrated operator is dependent form the site rental price and the profitability of the WLAN service provider model from the roaming price. These prices are determined by the expectation of the location owner's business case (including the benefits of his main business) and the attractiveness of the location for the value partners. This should be considered in the next evaluation of the business models. Therefore also the type of the location should be considered in the next design phase.

- The success of the fully integrated operator and the WLAN service provider model relay on the ability to provide a better coverage through access in multi locations. Therefore the rollout and the roaming strategy should be considered more in detail in design module in the next iteration.

- Enhanced Network Services are too complex for small operators and professional access providers + who want to offer services like IP-Telephony and Push Services. There is a need for an enhanced Network Service ASP, offering an enabling platform. This new value activity and proposition should be considered in the next design phase. 


\section{Conclusion}

We have gathered new insides regarding the PWLAN industry. We have ...

- ... identified that the "ownership" and the "composition of the value chain" are the new design dimensions with the highest impact on the business model

- ... designed potential business models and gave an assumption how viable they are - noteworthy is that the number of potential business model decrease with an increased user penetration, as customer expectation changes.

- ... outlined the dynamics of the new WLAN industry and how the business model will interact. Most assumed competition is between the business models fully integrated operator, WLAN service provider and relationship mgt ASP. Biggest profitability will be realized in the value activity access of some location types and in the relationship mgt.

The IDEA framework supported us in the development of the new PWLAN business models and helped us to better understand this new industry and thus fulfilled the initial formulated goal. We recommend using this framework also for other industries, where their basic assumptions have been changed by a new technology or other events (e.g. new regulatories).

\section{Acknowledgment}

The authors would like to thank the two anonymous reviewers for their valuable comments.

\section{References}

[Acad02] Academic Press Inc.: http://www.academicpress.com/inscight/ 08211997/ competi1.htm, seen on 04.09.2002.

[AfTu01]. Afuah, A.; Tucci, C.: Internet Business Models and Strategies - Text and Cases New York (McGraw-Hill) 2001.

[AlZi01] Alt, R., Zimmermann, H.-D.: Preface: Introduction to Special Section - Business Models (Vol. 11, No. 1: Guest Editors Note), in: EM - Anniversary Edition: Business Models. EM - The International Journal on Business Media and Electronic Markets, 11(1), 2001. www.electronicmarkets.org 
[FuPo86] Fuller, Mark B.; Porter, Michael E.: Coalitions and Global Strategy from: Porter, Michael E. (Hrsg.): Competition in Global Industries Boston, Massachusetts (HBS Press) 1986. S. 315-344.

[Grif02] Griffith, Eric: Validating the Hotspot Model? http://www.80211planet.com/news/article/ 0,4000,1481_1453341,00.html, seen on 27.08.2002.

[Hame03] Hamel, G.: Leading the Revolution. Harvard Business Press, (Rev. and Updated Rev.), 2003.

[HeCl90] Henderson, R.; Clark, K.: Architectural Innovation: The Reconfiguration of Existing Product Technologies and the Failure of Established Firms In: Administratiive Science Quartely, 35. Jg. (1990), H. 35, S. 9-30.

[Heis03] Heise-Online: US-Firmen basteln an WLAN-Handy, http://www.heise.de/ newsticker/data/dz-16.01.03-000/, seen on 16.01 .03

[Monz02] Monzoon: http://www.monzoon.ch/sites/company/strategic1.html, seen on 02.09.2002.

[Nies ${ }^{+}$97] Nieschlag, Robert; Dichtl, Erwin; Hörschgen, Hans: Marketing. 18. durchges. Aufl. Berlin (Dunker und Humblot) 1997

[Lone02] Lonergan, Declan: Public Acess WLAN - A Technology in search for a business case? (Yankee Group) June 2002

[Pow02] Pow, Ross: Public Wireless LAN Access-Market Forecasts (Analysys) 2001

[Port88] Porter, Michael E.: Wettbewerbsstrategie Frankfurt a. M., New York (Campus) 1988.

[Port96] Porter, Michael E.: Wettbewerbsvorteile. Spitzenleistungen erreichen und behaupten Frankfurt a. M., New York (Campus) 1996.

[Slyw99] Slywotzky, A.: Strategisches Business-Design - zukunftsorientierte Konzepte zur Steigerung des Unternehmenswertes Frankfurt a. M., New York (Campus) 1997.

[Stäh01] Stähler, Patrick: Geschäftsmodelle in der digitalen Ökonomie: Merkmale, Strategien und Auswirkungen Lohmar, Köln (Josef Eul Verlag) 2001.

[Stähl01b] Stähler, Patrick: Business Model Innovation http://www.business-modelinnovation.com/definitionen/geschäftsmodellinnovation.html 2001b, on 28.08.2002

[Tewe97] Tewes, Daniel: Chancen und Risiken netzunabhängiger Service Provider - Diskussionsbeitrag Nr. 179 Bad Honnef (WIK) 1997

[Thor02] Thorgren, B.: European WISP venues. (Brain Capital) Dec. 2002

[Timm98] Timmers, P.: Business Models for Electronic Markets. EM - Electronic Markets. The International Journal of Electronic Markets and Business Media 3. (www.electronicmarkets.ch)

[Zobe01] Zobel, Dietmar: Systematisches Erfinden, Renningen (Expert-Verlag) 2001

[Zwic66] Zwicky, Fritz: Entdecken, Erfinden, Forschen im Morphologischen Weltbild München, Zürich (Droememersche Verlagsanstalt) 1966. 